\title{
STUDI KUAT LENTUR BETON DENGAN BAHAN TAMBAH SERAT ABAKA
}

\author{
Yudi Pranoto $^{1)}$, Lina Halim ${ }^{2)}$, Anung Sudibyo ${ }^{3)}$ \\ Politeknnik Negeri Samarinda \\ Email: yudipranoto@polnes.ac.id ${ }^{1)}, \underline{\text { linahalim@yahoo.com }}{ }^{2)}$, \\ bpk.anungsudibyo@gmail.com ${ }^{3)}$
}

DOI: http://dx.doi.org/10.29103/tj.v11i1.364

(Received: August 2020 / Revised: December 2020 / Accepted: January 2021)

\begin{abstract}
Abstrak
Serat abaka merupakan serat yang awet dan lentur yang diambil dari pohon pisang. Serat ini masih sangat jarang dimanfaatkan, sementara di Indonesia serat abaka bisa ditemukan di mana mana. Tujuan penelitian ini adalah untuk mengetahui sejauh mana pengaruh serat abaka terhadap kuat lentur beton. Penelitian ini diawali dengan studi literature, pengujian material (Agregat halus, agregat kasar, semen dan serat abaka), mix design beton, pembuatan benda uji, perawatan dan dilanjutkan dengan pengujian kuat lentur beton serta terakhir dilakukan analisis hasil pengujian. Dari hasil pengujian didapatkan kuat lentur maksmum terjadi pada kadar serat abaka sebesar $0,6 \%$ dengan kuat lentur 3,75 MPa, sedangkan kuat lentur terkecil terjadi pada kadar serat abaka $0 \%$ dengan kuat lentur 3,34 $\mathrm{MPa}$.
\end{abstract}

Kata kunci: serat abaka, kuat lentur, mix deisgn

\begin{abstract}
Abaca fiber is a durable and flexible fiber taken from the banana tree. This fiber is still very rarely used, while in Indonesian abaca fiber can be found everywhere. The purpose of this study was to determine the extent of the influence of abaca fiber on the flexural strength of concrete. This research begins with literature studies, material testing (fine aggregate, coarse aggregate, cement, and abaca fiber), concrete mix design, manufacture of test objects, curing, and continues with concretes flexural strength testing and finally an analysis of the test results. From the test results, it founded that the maximum flexural strength occurred at the abaca fiber content of $0.6 \%$ with a bending strength of $3.75 \mathrm{MPa}$, and the smallest flexural strength occurred at $0 \%$ abaca fiber content with a flexural strength of $3.34 \mathrm{MPa}$.
\end{abstract}

Keywords: Abaka fiber, flexural strength, mix design

\section{Latar Belakang}

Abaka merupakan tanaman penghasil serat yang termasuk famili Musaceae. Tumbuh liar di Pulau Mindanao (Filipina) dan Pulau Sangihe (Indonesia), karenanya abaka disebut sebagai Pisang Manila Hemp. Seratnya kuat dan tahan tergadap air. Serat abaka diambil terutama dari bagian batang. Kelebihan Manila Hemp adalah awet, lentur dan tahan salinitas. Serat abaka juga dipilih karena lebih ramah lingkungan dibandingkan dengan penggunaan serat buatan atau serat 
sintetis sebab bisa didaur ulang. Selain itu serat abaka mempunyai kekuatan, durabilitas yang tinggi dan lebih tahan terhadap air garam (Zulkifly et al., 2011) (Sampathkumar et al., 2012). Selain itu serat abaca dapat meningkatkan kuat lentur dan (Bledzki, Mamun and Faruk, 2007) (Akbar, 2011), namun penggunaan serat abaka dapat mengurangi kuat tekan beton (Hani and Rini, 2018). Serat abaka dapat meningkatkan modulus elastisitas mortar (Wibowo, 2011), digunakannya serat sabut kelapa karena, dengan adanya penambahan serat ini pada beton dapat meningkatkan kuat tekan beton yakni diperoleh kuat tekan optimum. Tujuan penelitian ini adalah untuk mengetahui sejauh mana pengaruh serat abaka terhadap kuat lentur beton.

\section{Metode Penelitian}

\subsection{Tahapan Penelitian}

Penelitian ini diawali dengan studi literature, pengadaan material dan dilanjutkan dengan pengujian material. Pengujian ini bertujuan untuk mengetahui sifat dan karakteristik bahan yang akan digunakan pada penelitian dan untuk mengetahui apakah bahan tersebut memenuhi persyaratan untuk digunakan sebagai bahan beton normal.

Setelah pengujian material selesai kemudian dilanjutkan dengan pembuatan campuran (mix desain) dengan mengacu pada (Badan Standarisasi Nasional, 2000), sehingga diperoleh komposisi bahan yang dibutuhkan untuk adukan beton. Jumlah sampel benda uji yang dibuat berjumlah 12 benda uji dengan variasi serat abaka $0 \% ; 0,4 \% ; 0,5 \%$ dan $0,6 \%$ (Tabel 2). Setelah pembuatan benda uji selesai beton kemudian dilakukan perawatan (curing) terhadap benda uji. Pada umur 28 hari beton dilakukan pengujian kuat lentur dengan benda uji berbentuk balok berukuran panjang $60 \mathrm{~cm}$, lebar $15 \mathrm{~cm}$, dan tinggi/tebal $15 \mathrm{~cm}$ pada umur 28 hari. Pengujian kuat lentur berdasarkan SNI 03-4431-2011. Data yang didapatkan dari hasil pengujian kemudian dianalisis untuk mengetahui pengaruh serat abaka terhadap kuat lentur beton.

\subsection{Serat Abaka}

Serat abaka Abaka merupakan tanaman penghasil serat yang termasuk famili Musaceae. Tumbuh liar di Pulau Mindanao (Filipina) dan Pulau Sangihe (Indonesia), karenanya abaka disebut sebagai Pisang Manila Hemp. Seratnya kuat dan tahan terhadap air. Serat abaka diambil terutama dari bagian batang.
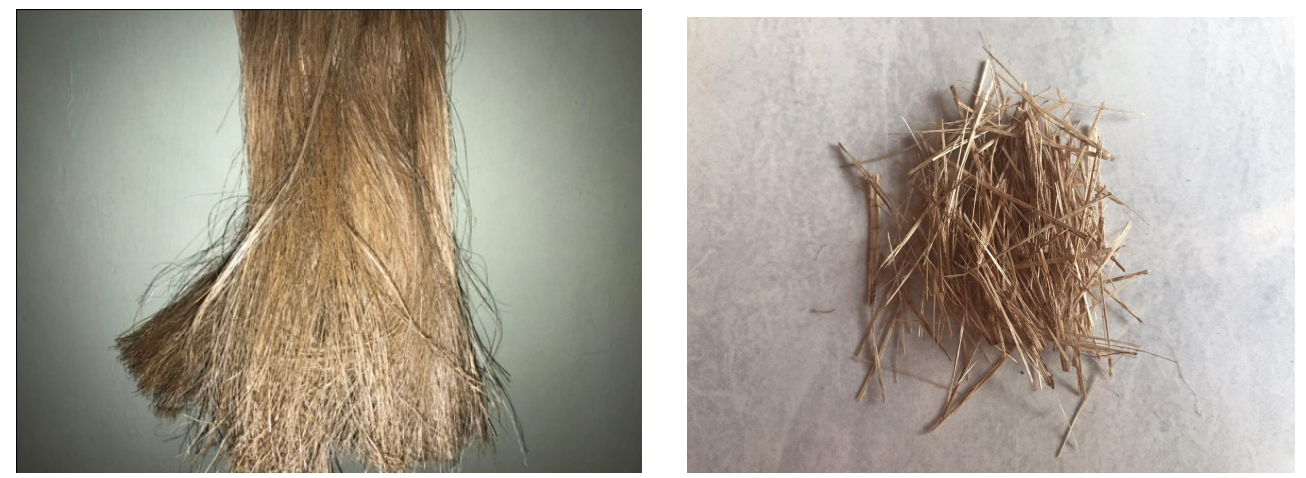

Gambar 1 Serat abaka sebelum dan setelah dipotong

Studi Kuat Lentur Beton Dengan Bahan Tambah Serat Abaka - Yudi Pranoto, Lina Halim, Anung Sudibyo 
Sebelum dipergunakan serat abaka dibersihkan dan dan dijemur, kemudian dipotong potong sepanjang $2 \mathrm{~cm}$. Serat yang telah dipotong kemudian ditimbang dengan berat $0,4 \% ; 0,5 \%$ dan $0,6 \%$ dari volume agregat halus. Bentuk serat abaka tampak seperti pada Gambar 1.

\subsection{Pengujian Material}

Sebelum dilakukan untuk penelitian, material yang akan dipergunakan (semen, agregat halus, agregat kasar dan serat abaka) dilakukan pengujian terlebih dahulu. Pengujian tersebut meliputi berat jenis dan penyerapan, analisa saringan, kadar air, kadar lumpur, bobot isi, abrasi, konsistensi normal, setting time dan berat jenis semen. Pengujian terhadap material tersebut mengikuti standar sesuai dengan Tabel 1.

Tabel 1 Standar pengujian material

\begin{tabular}{|c|c|c|c|c|}
\hline No & Jenis Pengujian & $\begin{array}{c}\begin{array}{c}\text { Standar Acuan } \\
\text { Pengujian }\end{array} \\
\end{array}$ & Standar & Hasil \\
\hline 1. & $\begin{array}{l}\text { Berat Jenis dan Penyerapan } \\
\text { Agregat Halus }\end{array}$ & SNI 03-1970-2008 & Min 2,5 & 2,51 \\
\hline 2. & $\begin{array}{l}\text { Berat Jenis dan Penyerapan } \\
\text { Agregat Kasar }\end{array}$ & SNI 03-1969-2008 & Min 2,54 & 2,63 \\
\hline 3. & Analisa Saringan & SNI 03-1968-1990 & & \\
\hline 4. & \begin{tabular}{l}
\multicolumn{2}{l}{ Kadar Air } \\
$-\quad$ Agregat halus \\
$-\quad$ Agregat kasar \\
\end{tabular} & SNI 03-1971-2011 & $\begin{array}{c}\text { Mak 6\% } \\
\text { Mak 1,3\% }\end{array}$ & $\begin{array}{c}1,88 \% \\
0,6 \% \\
\end{array}$ \\
\hline 5. & \begin{tabular}{ll}
\multicolumn{2}{l}{ Kadar Lumpur } \\
$-\quad$ Agregat halus \\
$-\quad$ Agregat Kasar \\
\end{tabular} & SNI 03-4141-1996 & $\begin{array}{l}\text { Mak 5\% } \\
\text { Mak } 1 \% \\
\end{array}$ & $\begin{array}{l}3,09 \% \\
0,42 \%\end{array}$ \\
\hline 6. & \begin{tabular}{ll}
\multicolumn{2}{l}{ Bobot Isi } \\
$-\quad$ Agregat halus \\
$-\quad$ Agregat Kasar \\
\end{tabular} & SNI 03-4804-1998 & $\begin{array}{l}\text { Min } 1,3 \\
\text { Min 1,3 }\end{array}$ & $\begin{array}{l}1,34 \\
1,59 \\
\end{array}$ \\
\hline 7. & Abrasi & SNI 03-2417-2008 & $\leq 40 \%$ & 23,21 \\
\hline 8. & Konsistensi Normal & SNI 03-6826-2002 & $24-30$ & 24,1 \\
\hline 9. & $\begin{array}{l}\text { Setting Time } \\
\text { Pengikatan awal } \\
\text { Pengikatan akhir }\end{array}$ & SNI 03-6827-2002 & $\begin{array}{c}\text { Min } 45 \\
\text { Max } 375\end{array}$ & $\begin{array}{c}47,3 \\
135\end{array}$ \\
\hline 10. & Berat Jenis Semen & SNI 15-2531-1991 & $3-3,2$ & 3,012 \\
\hline
\end{tabular}

Pengujian konsistensi normal menggunakan standar SNI 03-6826-2002 yang bertujuan menentukan menentukan kadar air yang dibutuhkan, di mana dapat menghasilkan rekatan yang optimum (Badan Standarisasi Nasional, 2002). Pengujian setting time menggunakan SNI 03-6827-2002, pengujian ini untuk mengetahui waktu yang diperlukan untuk mengerasnya semen terhitung dari bereaksinya semen dengan air yang menjadi pasta semen hingga cukup untuk menerima tekanan (Badan Standardisasi Nasional, 2002). Berat jenis semen menggunakan standar SNI 15-2531-1991 (Standar Nasional Indonesia, 2015), pengujian ini bertujuan untuk mengetahui berat jenis semen. Pengujian bobot isi 
semen menggunakan SNI 03-4804-1998 (Badan Standarisasi Nasional, 1998). Untuk agregat halus dan agregat kasar dilakukan beberapa pengujian. Pengujian tersebut antara lain pengujian kadar air menggunakan standar SNI 03-1971-2011 (Badan Standarisasi Nasional, 2011). Pengujian ini bertujuan untuk mengetahui persentase air yang terdapat dalam agregat. Kemudian pengujian bobot isi mengacu pada SNI 03-4804-1998 (Badan Standarisasi Nasional, 1998). Analisa saringan mengacu pada SNI 03-1968-1990 (Badan Standardisasi Nasional, 1990), kadar lumpur mengacu SNI 03-4141-1996 (Badan Standarisasi Nasional, 2019). Berat jenis dan penyerapa agregat halus menggunakan SNI 03-1970-2008, sedangkan untuk agregat kasar SNI-1969-2008 (Badan Standar Nasional Indonesia, 2008). Dari hasil pengujian semua persyaratan sesuai dengan SNI.

\subsection{Mix Design Beton}

Perencanaan campuran (mix desain) pada penelitian ini mengacu pada (Badan Standarisasi Nasional, 2000) untuk beton normal. Pada rancangan campuran beton ini akan diperoleh komposisi bahan yang diperlukan untuk adukan beton normal. Variasi Serat Abaka (VSA) dan jumlah benda uji dapat dilihat pada Tabel 2.

Tabel 2 Variasi benda uji

\begin{tabular}{cccc}
\hline No. & $\begin{array}{c}\text { Kode Benda } \\
\text { Uji }\end{array}$ & $\begin{array}{c}\text { Variasi Serat } \\
\text { Abaka }\end{array}$ & $\begin{array}{c}\text { Jumlah } \\
\text { Sampel }\end{array}$ \\
\hline 1 & VSA 0 & $0 \%$ & 3 \\
\hline 2 & VSA 0,4 & $0,4 \%$ & 3 \\
\hline 3 & VSA 0,5 & $0,5 \%$ & 3 \\
\hline 4 & VSA 0,6 & $0,6 \%$ & 3 \\
\hline \multicolumn{4}{c}{ Total benda uji } \\
\hline
\end{tabular}

\subsection{Pembuatan Benda Uji}

Pembuatan benda uji yang direncanakan adalah sebanyak 12 sampel, dengan masing-masing variasi campuran memiliki 3 buah benda uji, dan masingmasing pengujian diberi kode atau nama pada setiap sampelnya.

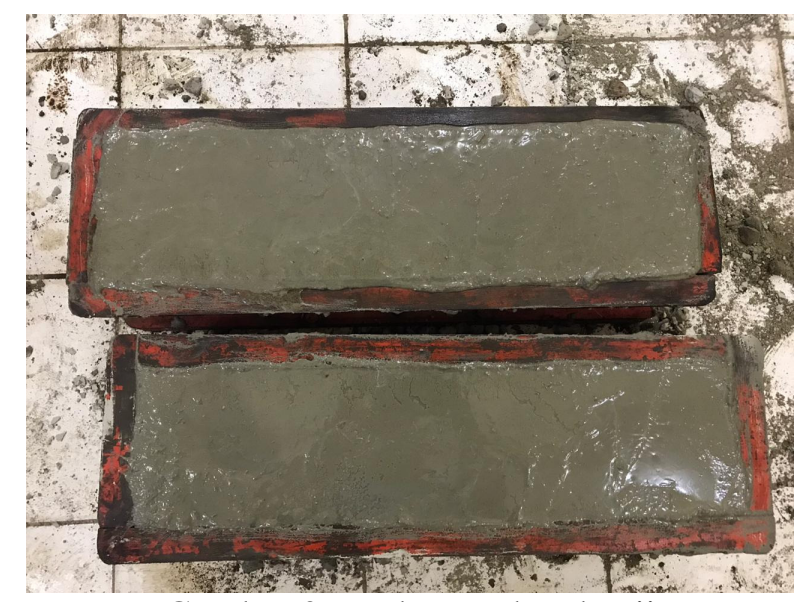

Gambar 2 pembuatan benda uji

Studi Kuat Lentur Beton Dengan Bahan Tambah Serat Abaka - Yudi Pranoto, Lina Halim, Anung Sudibyo 
Dalam penelitian ini diberi symbol VSA (Variasi Serat Abaka). Benda uji tersebut di uji setelah beton berumur 28 hari. Cetakan beton serat abaka terlihat seperti Gambar 2. Rencana kuat lentur yang ingin dicapai adalah 3,5 Mpa.

\subsection{Perawatan Benda Uji}

Perawatan (curing) dimaksudkan untuk menghindari panas hidrasi yang tidak diinginkan, dan untuk memastikan reaksi hidrasi senyawa semen termasuk bahan tambahan atau bahan pengganti dapat berlangsung secara optimal sehingga mutu beton yang diharapkan dapat tercapai. Setelah dicetak benda uji dilakukan perawatan direndam didalam bak rendam di laboratorium teknik Sipil, Politeknik Negeri Samarinda.

\subsection{Pengujian Benda Uji}

Pada tahap ini dilakukan pengujian kuat lentur dengan benda uji berbentuk balok berukuran panjang $60 \mathrm{~cm}$, lebar $15 \mathrm{~cm}$, dan tinggi $15 \mathrm{~cm}$ pada umur 28 hari (Gambar 3). Pengujian kuat lentur berdasarkan (Badan Standar Nasional Indonesia, 2011). Perhitungan kuat lentur beton dihitung sesuai dengan persamaan di bawah ini.

$$
\sigma=\frac{P . L}{b \cdot h^{2}}
$$

Keterangan:

$\sigma=$ kuat lentur benda uji (MPa)

$\mathrm{P}=$ beban tertinggi yang terbaca pada mesin uji $(\mathrm{kN})$

$\mathrm{L}=$ jarak (bentang) antara dua garis perletakan $(\mathrm{mm})$

$\mathrm{b}=$ lebar tampang lintang patah arah horizontal $(\mathrm{mm})$

$\mathrm{h}=$ lebar tampang lintang patah arah vertikal $(\mathrm{mm})$

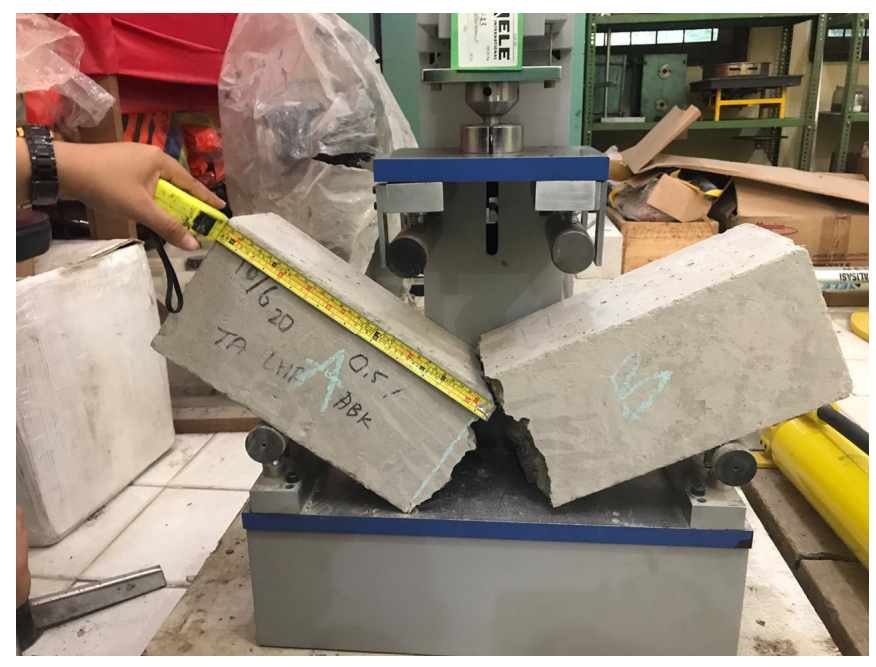

Gambar 3 Pengujian kuat lentur beton serat abaka 


\section{Hasil dan Pembahasan}

Dari hasil pengujian didapatkan kuat lentur beton serat abaka seperti diperlihatkan pada Tabel 3 dan Gambar 4.

Tabel 3 Hasil pengujian kuat lentur serat abaka

\begin{tabular}{cccc}
\hline & $\begin{array}{c}\text { Umur Pengujian } \\
\text { Variasi }\end{array}$ & $\begin{array}{c}\text { Variasi Serat } \\
\text { Abaka } \\
(\%)\end{array}$ & $\begin{array}{c}\text { Kuat Lentur } \\
(\text { Hari) }\end{array}$ \\
\cline { 2 - 4 } Serat & 28 & 0,0 & \\
\cline { 2 - 4 } Abaka & 28 & 0,4 & 3,41 \\
\cline { 2 - 4 } & 28 & 0,5 & 3,68 \\
\cline { 2 - 4 } & 28 & 0,6 & 3,75 \\
\hline
\end{tabular}

\section{GRAFIK KUAT LENTUR}

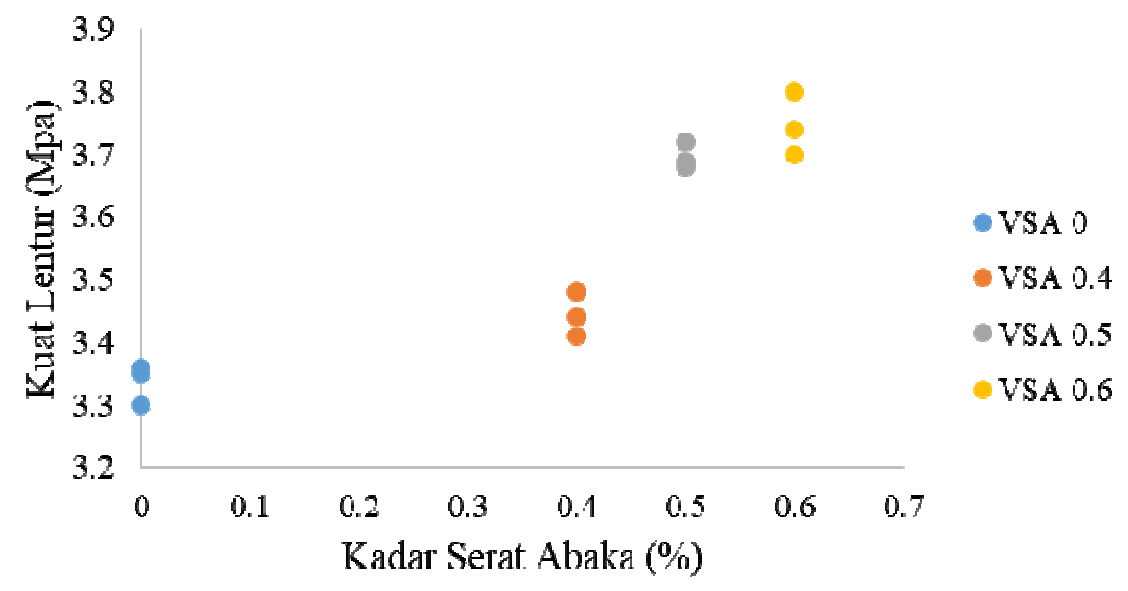

Gambar 4 Grafik hasil pengujian kuat lentur beton serat abaka

Dari grafik tersebut terlihat dengan bertambahnya serat abaka dapat meningkatkan kuat lentur beton. Hal ini bisa dilihat dari semua variasi penambahan serat, hasil kuat lenturnya di atas kuat lentur beton normal. Kuat lentur terbesar terjadi pada beton dengan kadar serat sebesar $0,6 \%$ dengan kuat lentur rata rata sebesar 3,75 MPa. Dalam grafik juga terlihat bahwa sampai dengan kadar serat $0,6 \%$ kuat lentur beton belum terjadi penurunan kuat lentur, namun grafik sudah mulai datar. Hal ini menunjukan bahwa kadar serat abaka $0,6 \%$ sudah mulai mendekati puncak kuat lentur.

\section{Kesimpulan dan Saran}

\subsection{Kesimpulan}

Penambahan Serat Abaka pada campuran beton dapat mempengaruhi nilai kuat lentur beton, dimana pada persentase $0 \%, 0,4 \%, 0,5 \%$ dan $0,6 \%$ dengan nilai kuat lentur berturut-turut 3,34 MPa, 3,41 MPa, 3,68 MPa dan 3,75 MPa. Dari hasil tersebut terlihat bahwa dengan adanya penambahan serat abaka dapat 
meningkatkan kuat lentur beton bila dibandingkan dengan yang tanpa penambahan serat abaka. Bertambahnya kadar serat abaka dapat meningkatkan kuat lentur beton, namun pada kadar serat abak 0,6\%, penambahan kuat lentur hanya sedikit, hal ini menandakan bahwa kadar optimum serat abaka sudah mulai terlihat.

\subsection{Saran}

Dapat dilakukan penelitian selanjutnya terkait dengan penambahan serat abaka sebagai bahan tambah pada campuran beton, sehingga dapat diketahui kadar optimum serat abaka yang dapat dipergunakan pada campuran beton.

\section{Ucapan Terima Kasih}

Ucapan terimakasih kepada semua pihak yang telah membantu dalam penelitian ini, terutama untuk Politeknik Negeri Samarinda yang telah membantu terlaksananya penelitian ini.

\section{Daftar Kepustakaan}

Akbar, D. P. . (2011) Pengaruh Penambahan Serat Abaka terhadap Kuat Lentur Geopolymer Mortar Berbahan Dasar Abu Terbang.

Badan Standar Nasional Indonesia (2008) SNI 1969-2008, Cara uji berat jenis dan penyerapan air agregat kasar. Jakarta.

Badan Standar Nasional Indonesia (2011) Cara uji kuat lentur beton normal dengan dua titik pembebanan, SNI 4431:2011.

Badan Standardisasi Nasional (1990) 'SNI 03-1968-1990 Metode Pengujian Tentang Analisis Saringan Agregat Halus dan Kasar', Badan Standar Nasional Indonesia, pp. 1-5. Available at: http://staff.uny.ac.id/sites/default/files/pendidikan/dr-slamet-widodo-stmt/sni-03-1968-1990.pdf.

Badan Standardisasi Nasional (2002) SNI 03-6827-2002, Metode Pengujian Setting Time.

Badan Standarisasi Nasional (1998) SNI 03-4804-1998, Metode Pengujian Bobot Isi dan Rongga Udara dalam Agregat, Balitbang PU.

Badan Standarisasi Nasional (2000) SNI 03-2834-2000: Tata cara pembuatan rencana campuran beton normal, Standar Nasional Indonesia.

Badan Standarisasi Nasional (2002) SNI 03-6826-2002, Metode Pengujian Konsistensi Normal.

Badan Standarisasi Nasional (2011) SNI 1971:2011, Cara Uji Kadar Air Total Agregat Dengan Pengeringan. Jakarta.

Badan Standarisasi Nasional (2019) SNI 03-4141-1996, Metode Pengujian Gumpalan Lempung.

Studi Kuat Lentur Beton Dengan Bahan Tambah Serat Abaka - Yudi Pranoto, Lina Halim, Anung Sudibyo 
Bledzki, A. K., Mamun, A. A. and Faruk, O. (2007) 'Abaca fibre reinforced PP composites and comparison with jute and flax fibre PP composites', Express Polymer Letters, 1(11), pp. 755-762. doi: 10.3144/expresspolymlett.2007.104.

Hani, S. and Rini (2018) 'Pengaruh Campuran Serat Pisang Terhadap Beton', Educational Building, 4(1), pp. 40-45. doi: 10.24114/eb.v4i1.10043.

Sampathkumar, D. et al. (2012) 'Effect of chemical treatment on water absorption of areca fiber', Journal of Applied Sciences Research, 8(11), pp. 52985305.

Standar Nasional Indonesia (2015) SNI 2531:2015 Metode Uji Densitas Semen Hidraulis, Bandung. Available at: http://infolpk.bsn.go.id/index.php?/sni_main/sni/detail_sni/22224.

Wibowo, B. . (2011) Pengaruh Penambahan Serat Abaka terhadap Slant Shear Fly Ash Based Geopolymer Mortar. Solo.

Zulkifly et al. (2011) 'Pengaruh Penambahan Serat Sabut Kelapa Terhadap Kuat Tekan Beton pada Beton Normal', Pengaruh Penambahan Serat Sabut Kelapa Terhadap Kuat Tekan Beton Pada Beton Normal, 1(2), pp. 121128. Available at: http://www.konsumerkini.net.my/v1/index.php/beritaterkini/polisi-awam/738-memahami-akta-pengurusan-sisa-pepejal-danpembersihan-awam-2007-akta-672. 